\title{
Ovine Proinflammatory Cytokines Cross the Murine Blood-Brain Barrier by a Common Saturable Transport Mechanism
}

\author{
Steven W. Threlkeld ${ }^{a, b}$ Jessica L. Lynch ${ }^{c}$ Kristin M. Lynch ${ }^{c}$ \\ Grazyna B. Sadowska ${ }^{a, b}$ William A. Banks ${ }^{c}$ Barbara S. Stonestreet ${ }^{a, b}$ \\ ${ }^{a}$ Warren Alpert Medical School of Brown University, and ${ }^{b}$ Department of Pediatrics, Women and Infants \\ Hospital of Rhode Island, Providence, R.I., and 'GRECC, Veterans Affairs Medical Center and Division of Geriatrics, \\ Department of Internal Medicine, Saint Louis University School of Medicine, Saint Louis, Mo., USA
}

\section{Key Words}

Blood-brain barrier - Cytokines · Neuroimmune axis •

Ovine interleukins

\begin{abstract}
Objectives: The cytokines interleukin (IL)-1 $\beta$ and IL- 6 are modulators of the neuroimmune axis and have been implicated in neuronal cell death cascades after ischemia or infection. Previous work has shown that some cross-species conservation exists between human and rodent blood-brain barrier (BBB) transport systems. To further assess cross-species conservation of cytokine transport across the BBB, the current studies investigated permeability and inhibition of ovine IL-1 $\beta$ and IL- 6 in the mouse. Methods: IL-1 $\beta$ or IL- 6 was radioactively labeled with ${ }^{131} \mathrm{I}$ and injected into the jugular vein at time zero. A subset of mice received 1 or $3 \mu \mathrm{g} / \mathrm{mouse}$ of an unlabeled ovine or murine cytokine (IL-1 $\beta$ or IL-6) to assess self- and/or cross-inhibition of transport. Permeability was assessed using multiple-regression analysis. Results: There was a significant linear relationship for both ovine ${ }^{131} \mid$ IL-1 $\beta$ and ${ }^{131} \mathrm{I}-\mathrm{IL}-6$ between brain/serum ratios and exposure time, indicating BBB permeability. Inclusion of $3 \mu \mathrm{g} / \mathrm{mouse}$ unlabeled ovine IL- $1 \beta$ or IL- 6 significantly reduced the trans-
\end{abstract}

\section{KARGER}

(c) 2010 S. Karger AG, Basel

Fax +41613061234 E-Mail karger@karger.ch www.karger.com www.karger.com/nim port of ovine ${ }^{131} \mathrm{I}-\mathrm{IL}-1 \beta$ or ${ }^{131} \mathrm{I}-\mathrm{IL}-6$, respectively, across the BBB. Transport of both ovine ${ }^{131} \mathrm{I}-\mathrm{IL}-1 \beta$ and ${ }^{131} \mathrm{I}-\mathrm{IL}-6$ was significantly inhibited by $1 \mu \mathrm{g} / \mathrm{mouse}$ of murine IL-1 $\beta$ or IL-6, respectively. In contrast, $1 \mu \mathrm{g} /$ mouse of unlabeled ovine IL$1 \beta$ or IL- 6 did not inhibit the transport of murine ${ }^{131} \mathrm{I}-\mathrm{IL}-1 \beta$ or ${ }^{131}$ I-IL-6. Conclusions: Ovine IL-1 $\beta$ and IL- 6 cross the mouse BBB by saturable transport. Inhibition of transport by murine homologs indicates that both species use the same transport mechanisms. Conversely, an inability of ovine cytokines to significantly inhibit the transport of murine cytokines indicates that mouse BBB has a lower affinity for ovine than murine cytokines. Knowledge of species-conserved BBB transport mechanisms may facilitate the development of novel animal models of central nervous system pathogenesis.

Copyright $\odot 2010$ S. Karger AG, Basel

\section{Introduction}

Neuroimmune interactions have gained increasing attention as research focused on neurodegenerative pathogenesis, and brain injury continues to implicate immune responses and cytokine upregulation in a variety of central nervous system (CNS) disorders including stroke, 
multiple sclerosis and infection [1-7]. Despite historical doubts about the transport and interaction of peripherally derived cytokines with CNS function and disease, research continues to reveal mechanisms for cytokine transport across the intact and damaged blood-brain barrier (BBB) [7-10]. Proinflammatory cytokines such as interleukin-1 $\beta$ (IL-1 $\beta$ ) and interleukin-6 (IL-6) have been shown to cross the murine BBB by saturable transport systems [8-11]. This saturable transport involves nonionic-driven protein-mediated transfer across the BBB [1]. Importantly, despite the fact that the BBB impedes leakage of molecules into the brain, it also serves as an interface for regulatory proteins [1]. Cytokines are one such family of regulatory proteins, with a diverse set of functions, which have been implicated in normal and pathological conditions $[1,12]$. A number of animal models continue to be used to address critical questions regarding species-conserved mechanisms of cytokine transport through the BBB, with potential implications for human neurological disorders and pathological modeling.

Saturable BBB transport systems have been identified for a number of murine cytokines including, IL-1 $\beta$, IL$1 \alpha$, IL- 6 and tumor necrosis factor- $\alpha$ (TNF- $\alpha$ ). Further, cross-species studies have shown some conservation of these mechanisms. For example, human IL- 6 and IL-1 $\alpha$ cross the murine BBB by saturable transport although with less affinity than the murine homologs, which share $60-70 \%$ amino acid identity to human ILs [13-15]. However, these mechanisms were not conserved for human IL-1 $\beta$ and TNF- $\alpha$ when assessed for murine BBB permeability $[16,17]$. Although a number of different species, including murine and ovine, have been used independently to examine BBB transport mechanisms and general permeability across ontogeny $[1,18,19]$, cross-species studies continue to be undertaken to assess phylogenetically conserved transport systems. The mouse represents a highly efficacious model for assessing BBB permeability from a logistical standpoint given the relatively low cost to achieve statistical power. Nonetheless, kinetic studies of BBB function cannot be performed in murine fetuses or newborns because of size limitations and because vascular access is not feasible.

Recent findings suggest that proinflammatory cytokines are important in the pathogenesis of brain damage in premature human infants [20-25]. Further, evidence also suggests that white matter lesions produced in the ovine fetus are similar to the lesions of periventricular leukomalacia, which represent an important antecedent of cerebral palsy in premature infants [26-28]. These findings $[26,29]$ collectively suggest that the preterm ovine fetus is an excellent model for the brain damage observed in premature human infants [26, 29-31]. Therefore, models of neuroinflammation related to cytokine upregulation and BBB permeability in the ovine fetus may represent a more ethological model of human in utero pathogenesis because of the ovine's extended gestational length, ability for real-time physiological monitoring and the frequency of single fetuses as compared with the mouse $[18,19,26,29,32]$. Therefore, complementary cross-species studies assessing BBB transport mechanisms in mice - before more detailed studies in ovine models - may shed light on evolutionarily conserved systems and provide a steppingstone for the development of ethologically relevant models of neuropathogenesis related to the regulation of proinflammatory cytokines.

Although murine and ovine IL-1 $\beta$ and IL- 6 share approximately 58 and $40 \%$ identity, respectively, based on basic local alignment search tools $[33,34]$, the ability of human ILs to cross the murine BBB and bind to the same receptors suggests species-conserved mechanisms despite variation in protein homology $[14,15,35]$. Therefore, we assessed the ability of radioactively iodinated ovine IL-1 $\beta\left({ }^{131} \mathrm{I}-\mathrm{IL}-1 \beta\right)$ and $\left({ }^{131} \mathrm{I}-\mathrm{IL}-6\right)$ to enter the murine brain after intravenous injection. We further assessed the ability of ovine and murine IL- $1 \beta$ and IL- 6 to self- and cross-inhibit the entry of ${ }^{131}$ I-IL- 6 and ${ }^{131}$ I-IL-1 $\beta$ into the murine brain. These studies may facilitate the development of novel animal models of CNS pathogenesis related to BBB permeability.

\section{Materials and Methods}

\section{Subjects}

Subjects were 8- to 12 -week-old male CD-1 mice from our inhouse colony. Mice were provided food and water ad libitum. All procedures and protocols comply with the National Institutes of Health guide for care and use of laboratory animals. All procedures were approved by the Institutional Animal Care and Use Committee of Veterans Affairs Medical Center of Saint Louis and the Saint Louis University School of Medicine.

\section{Purification and Iodination of Cytokines}

Ovine IL-1 $\beta$ and IL- 6 were obtained from Commonwealth Scientific and Industrial Research Organization (CSIRO) Animal Health (Parkville, Vic., Australia) that had been cultivated in certified (virus-free) culture broths. The bacterial samples were lysed, sonicated, the proteins column-purified, and then sterile filtered to remove any possibility of bacterial contamination as previously described (for IL-1 $\beta[36,37]$ and IL-6 [38]). The purity of ovine IL- 6 was $95 \%$ and that of IL- $1 \beta$ was $90 \%$ as evidenced by SDS-PAGE and Western immunoblot analysis, consistent with that described by McWaters et al. [38] and Rothel et al. [36], re- 
spectively, using the same methods. Murine cytokines (IL-1 $\beta$ and IL-6) were obtained from R\&D Systems (Minneapolis, Minn., USA). The IL-1 $\beta$ s were labeled with ${ }^{131}$ I by the chloramine-T method and purified on a column of Sephadex G-10 as previously applied to IL-1 [14]. Briefly, the iodinated IL-1 $\beta$ s were separated from free iodine on a column of G-10 Sephadex that had been hydrated in $0.25 \mathrm{M}$ phosphate buffer with $1 \%$ BSA. Prior to separation of the iodination mixture, the column was washed free of excess BSA with phosphate buffer, which was also used to elute the radiolabeled ILs. The IL- 6 s were labeled with ${ }^{131}$ I by the lactoperoxidase method as previously described [39]. Briefly, IL-6s were mixed with a solution of $0.4 \mathrm{M}$ sodium acetate ( $\mathrm{pH}$ 5.6), lactoperoxidase $(10 \mu \mathrm{g} / \mathrm{ml})$, and $1 \mathrm{mCi}$ of ${ }^{131} \mathrm{I}$ and purified with high performance liquid chromatography. Chloramine-T was used for IL-1 $\beta$ radiolabeling because of its higher labeling efficiency as compared to the lactoperoxidase method. However, IL-6 was labeled with lactoperoxidase given that IL- 6 does not remain biologically active following chloramine-T-mediated radiolabeling.

\section{Measurement of Influx Rate}

Subjects were anesthetized with urethane and the right jugular vein and left carotid artery were exposed as previously described [39]. Five micrograms of cytokine (IL-1 $\beta$ or IL-6) was radioactively labeled with $1 \mathrm{mCi}$ of ${ }^{131} \mathrm{I}$. Label integrity was evaluated using acid precipitation. If activity decreased to less than $90 \%$ of the original level, the material was excluded from the study. A volume of $0.2 \mathrm{ml}$ of Ringer's solution containing $1 \%$ by weight of BSA and $3 \times 10^{5}$ counts per minute (cpm) were injected into the jugular vein at time zero as previously described [39]. Blood was collected from the right carotid artery and the animals were decapitated between 1-15 min after the injection. Subsequently, the levels of radioactivity in brain and blood samples were measured in a gamma counter. A subset of mice received 1 or $3 \mu \mathrm{g} /$ mouse of an unlabeled ovine or murine cytokine (IL-1 $\beta$ or IL-6) included simultaneously with the labeled protein in order to assess affinity and/or cross-inhibition of transport. Cross-inhibition studies similar to those previously described [14] were conducted to determine whether the transporter for ovine IL- $1 \beta$ was the same as that previously identified for murine IL-1 $\beta$. The unidirectional influx rate from blood to brain $\left(\mathrm{K}_{\mathrm{i}}\right.$, in $\left.\mu \mathrm{l} / \mathrm{g} \cdot \mathrm{min}\right)$ and the initial volume of distribution in brain at time zero $\left(V_{\mathrm{i}}\right.$, in $\left.\mu \mathrm{l} / \mathrm{g}\right)$ were determined by multiple-time regression analysis. Importantly, $\mathrm{V}_{\mathrm{i}}$ accounts for the amount of radioactivity in the vascular space and endothelial receptor binding at time zero allowing for accurate calculation and correction of $\mathrm{K}_{\mathrm{i}}$. The brain/serum ratios (in $\mu \mathrm{l} / \mathrm{g}$ ) were plotted against exposure time (Expt, in $\mathrm{min}$ ):

$$
A m / C p t=K_{i}(\operatorname{Exp} t)+V_{i}
$$

where Am is the cpm/g of brain, Cpt is the cpm/ $\mu$ l of serum at time $(\mathrm{t})$, and

$$
\operatorname{Expt}=\left[\int_{0}^{t} C p(t) d \tau\right] / C p t
$$

where $t$ is the time and $d \tau$ is a dummy variable for time. Use of exposure time corrects for clearance of ${ }^{131}$ I-ILs from blood, mathematically creating a steady-state for the serum levels. The linear portion of the relation between brain/serum ratios and Expt is used to calculate $\mathrm{K}_{\mathrm{i}}$. Regression lines were compared statistically with the GraphPad Prism 5.0 program (GraphPad Inc., San Diego, Calif., USA).

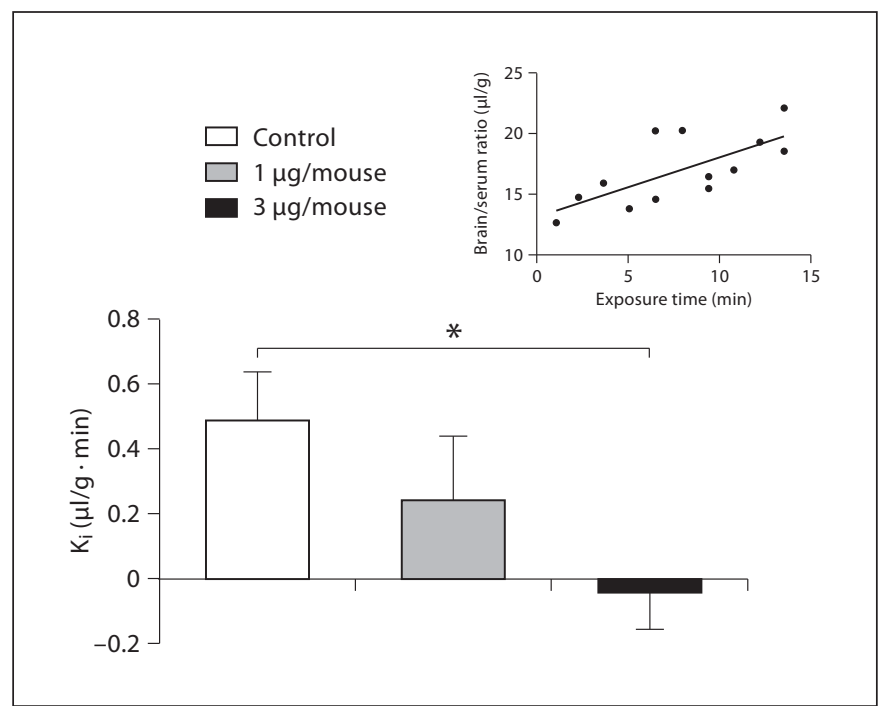

Fig. 1. The inset line graph shows a significant linear relationship between brain/serum ratios and exposure time for ovine ${ }^{131} \mathrm{I}$-IL$1 \beta$. Each point represents 1 subject. Histogram shows that inclusion of $3 \mu \mathrm{g} / \mathrm{mouse}$ but not $1 \mu \mathrm{g} /$ mouse of unlabeled ovine IL-1 $\beta$ significantly reduced the transport of ovine ${ }^{131}$ I-IL-1 $\beta$ across the BBB. Error bars are SEM. ${ }^{*} \mathrm{p}<0.05$.

\section{Results}

\section{IL-1 $\beta$ Permeability}

Results revealed a significant linear relationship between brain/serum ratios and $\operatorname{Expt}(\mathrm{r}=0.704, \mathrm{n}=13, \mathrm{p}<$ 0.01 ) for ovine IL-1 $\beta$ labeled with ${ }^{131} \mathrm{I}$ (ovine ${ }^{131} \mathrm{I}-\mathrm{IL}-1 \beta$ ), with the $\mathrm{K}_{\mathrm{i}}$ (slope) $=0.489 \pm 0.149 \mu \mathrm{l} / \mathrm{g} \mathrm{min}$ (fig. 1 , inset). Further, inclusion of $3 \mu \mathrm{g} / \mathrm{mouse}$ but not $1 \mu \mathrm{g} /$ mouse of unlabeled ovine IL-1 $\beta$ ( $\mathrm{n}=12$ with unlabeled, $\mathrm{n}=12$ without) significantly $[\mathrm{F}(1,22)=8.11, \mathrm{p}<0.01]$ reduced the transport of ovine ${ }^{131} \mathrm{I}-\mathrm{IL}-1 \beta$ across the $\mathrm{BBB}$, indicating a saturable transport mechanism (fig. 1). Cross-inhibition studies showed that the transport of ovine ${ }^{131} \mathrm{I}-\mathrm{IL}$ $1 \beta$ was significantly inhibited by $1 \mu \mathrm{g} / \mathrm{mouse}$ unlabeled murine IL-1 $\beta$ ( $\mathrm{n}=8$ with unlabeled, $\mathrm{n}=8$ without) [F (1, 14) $=8.92$, $\mathrm{p}<0.01$; fig. 2a]. However, administration of $1 \mu \mathrm{g} /$ mouse unlabeled ovine IL-1 $\beta$ was unable to significantly inhibit the transport of murine ${ }^{131} \mathrm{I}-\mathrm{IL}-1 \beta$ across the $\mathrm{BBB}$ despite a $30 \%$ decrease in $\mathrm{K}_{\mathrm{i}}$ (p NS; fig. 2b). Results indicate that murine $\mathrm{BBB}$ transport has a higher affinity for murine than ovine IL-1 $\beta$.

\section{IL-6 Permeability}

Results revealed a significant linear relationship between brain/serum ratios and exposure time (Expt) $(r=$ 
Fig. 2. Histograms showing that transport of ovine ${ }^{131} \mathrm{I}-\mathrm{IL}-1 \beta$ (a) was significantly inhibited by $1 \mu \mathrm{g} /$ mouse of unlabeled murine IL-1 $\beta$ and that transport of murine ${ }^{131}$ I-IL-1 $\beta$ (b) was not significantly inhibited by $1 \mu \mathrm{g} / \mathrm{mouse}$ of unlabeled ovine IL$1 \beta$. Error bars are SEM. ${ }^{*} \mathrm{p}<0.05$.

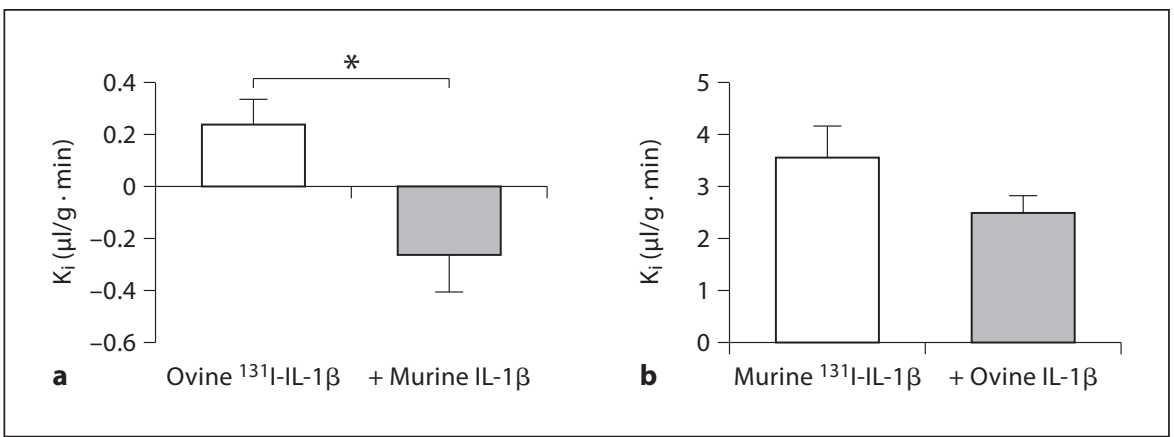

Fig. 3. Line graph showing a significant linear relation between brain/serum ratios and exposure time for ovine ${ }^{131}$ I-IL-6 (a) (each point represents 1 subject) and histograms showing that $3 \mu \mathrm{g} /$ mouse unlabeled ovine IL- 6 significantly inhibited the permeability of ovine ${ }^{131}$ I-IL- 6 (b), that $1 \mu \mathrm{g} /$ mouse unlabeled ovine IL- 6 was unable to inhibit the permeability of murine ${ }^{131} \mathrm{I}$-IL6 (c) and that $1 \mu \mathrm{g} /$ mouse of unlabeled murine IL- 6 was able to inhibit the transport of ovine ${ }^{131}$ I-IL- 6 across the BBB (d), indicating higher affinity for murine than ovine cytokine. Error bars are SEM. ${ }^{*} \mathrm{p}<$ 0.05 .
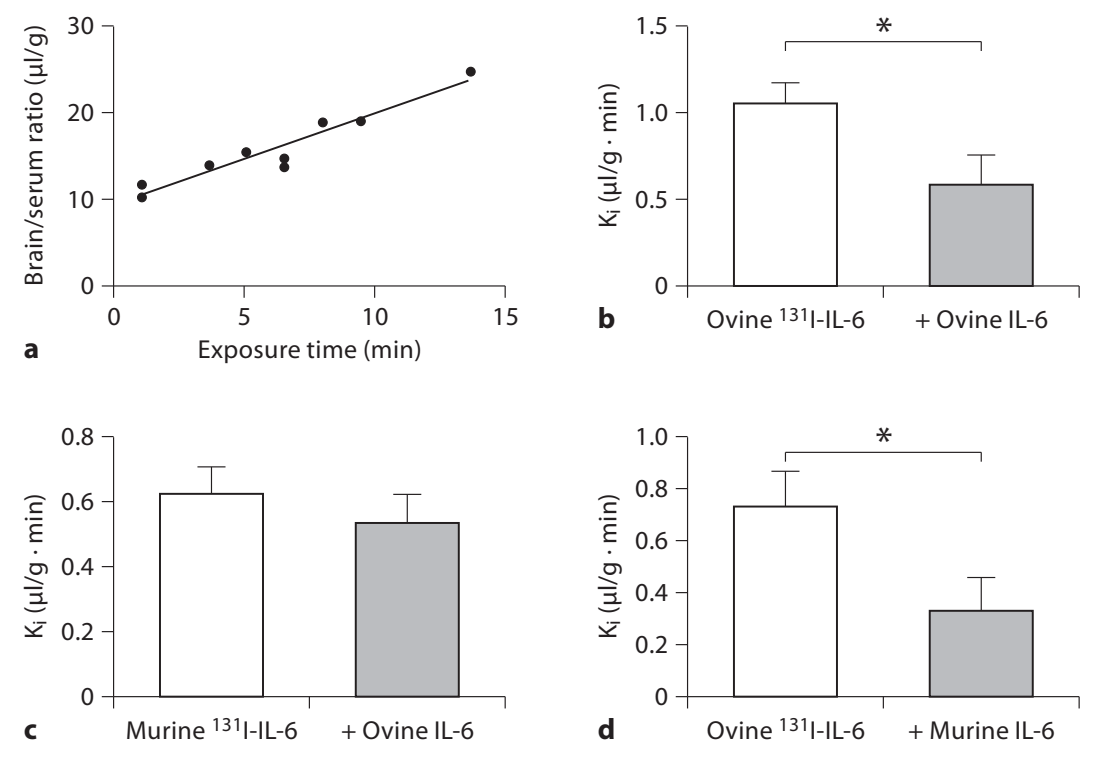

0.96, $\mathrm{n}=9, \mathrm{p}<0.001)$ for ovine ${ }^{131} \mathrm{I}-\mathrm{IL}-6$ with the $\mathrm{K}_{\mathrm{i}}$ (slope) $=1.049 \pm 0.123 \mu \mathrm{l} / \mathrm{g} \mathrm{min}$ (fig. 3a). Further, inclusion of $3 \mu \mathrm{g} / \mathrm{mouse}$ unlabeled ovine IL- 6 ( $\mathrm{n}=10$ with unlabeled, $\mathrm{n}=10$ without) significantly $[\mathrm{F}(1,18)=15.4$, $\mathrm{p}<0.001$ ] reduced the transport of ovine ${ }^{131}$ I-IL- 6 across the $\mathrm{BBB}$, indicating a saturable transport mechanism (fig. 3b). Cross-inhibition studies showed that the transport of murine ${ }^{131} \mathrm{I}-\mathrm{IL}-6$ was not inhibited by $1 \mu \mathrm{g} / \mathrm{mouse}$ of unlabeled ovine IL- 6 ( $\mathrm{p}=\mathrm{NS}$ ). In contrast, administration of $1 \mu \mathrm{g} / \mathrm{mouse}$ unlabeled murine IL-6 ( $\mathrm{n}=7$ with unlabeled, $\mathrm{n}=8$ without) significantly $[\mathrm{F}(1,13)=4.67$, $\mathrm{p}<0.05$ ] inhibited the transport of ovine ${ }^{131}$ I-IL-6 across the $\mathrm{BBB}$.

\section{Discussion}

These studies show that both ovine IL- $1 \beta$ and IL- 6 cross the $\mathrm{BBB}$ of the mouse by saturable transport. Specifically, results revealed a significant linear relationship between brain/serum ratios and exposure time for ovine IL-1 $\beta$ and ovine ${ }^{131}$ I-IL-6, demonstrating that these cytokines cross the murine BBB. Further, inhibition of ${ }^{131} \mathrm{I}-\mathrm{IL}$ (IL-1 $\beta$ and IL-6) transport by the murine homologs suggests competitive transport, and that ovine cytokines use the same transporters as those of the mouse. Importantly, inclusion of $3 \mu \mathrm{g} / \mathrm{mouse}$, but not $1 \mu \mathrm{g} / \mathrm{mouse}$, ovine IL-1 $\beta$ significantly reduced the transport of ovine ${ }^{131} \mathrm{I}-\mathrm{IL}$ $1 \beta$ across the BBB. Moreover, inclusion of $3 \mu \mathrm{g} / \mathrm{mouse}$ ovine IL-6, but not $1 \mu \mathrm{g} / \mathrm{mouse}$, significantly inhibited 
ovine ${ }^{131}$ I-IL- 6 transport into the murine brain. In contrast, transport of ovine ${ }^{131} \mathrm{I}-\mathrm{IL}-1 \beta$ and ${ }^{131} \mathrm{I}-\mathrm{IL}-6$ was significantly inhibited by only $1 \mu \mathrm{g} /$ mouse of murine IL-1 $\beta$ and IL-6, respectively. The inability of ovine cy tokines to inhibit the transport of murine cytokines significantly indicates that the mouse BBB has a lower affinity for ovine than murine cytokines.

The results presented above identify common saturable BBB transport mechanisms for ovine and murine IL$1 \beta$ and IL- 6 . Although the mode of transport appears to be conserved between species, ovine cytokines exhibit less affinity for transport as compared to their murine counterparts. These differences are likely to originate from clear disparities in amino acid homology, which may be reflected in the binding properties of the transport systems. Further, mouse ILs were able to inhibit entry of the ovine ILs, suggesting either multiple carriers with overlapping affinity or a single carrier able to transport both murine and ovine ILs across the BBB [14]. Regardless of the mechanism, it is clear that the murine system preferentially transports the native ILs over those of the ovine species. It should be emphasized that most cytokine transport systems are specific for closely related cytokines. For example, the IL-1 system is unable to transport TNF- $\alpha$ or IL-6 [9]. Further, across species, some cytokines have increased receptor selectivity and higher BBB uptake rates than others. For example, the mouse has a higher blood to brain transport rate of human ${ }^{125} \mathrm{I}-\mathrm{IL}-1 \alpha$ as compared to that of the rat $[1,17]$. Although variations in transport rates and affinities can be seen across species, saturable transport for cytokines IL$1 \beta$ and IL- 6 appears to be conserved for both the ovine and murine proteins. Given that similar transport systems have been observed for human, murine and now ovine ILs $[13,14]$, the current study opens the door to novel translational models of proinflammatory cytokine-mediated pathogenesis in the ovine $[19,26,29]$.

\section{Conclusions}

The current studies provide additional evidence that transport mechanisms for proinflammatory cytokines IL- $1 \beta$ and IL- 6 are conserved across several mammalian species, including ovine. Further, the ability of ovine cytokines to enter the murine brain from blood by saturable transport provides further support for a strong link between the peripheral immune system and the CNS. Finally, the present findings provide a starting point for more in-depth investigations of BBB permeability and cytokine-mediated pathogenesis in highly valuable ovine models of human neurodevelopmental pathology.

\section{Acknowledgements}

This research was supported by NIH grants 1R01-HD-057100 and NIH RO1 AG029839 and VA merit review. We also gratefully acknowledge CSIRO Animal Health (Parkville, Vic., Australia) for their generous gift of IL- 6 and IL-1 $\beta$.

\section{References}

1 Banks WA: Blood-brain barrier transport of cytokines: a mechanism for neuropathology. Curr Pharm Des 2005;11:973-984.

$\checkmark 2$ Barone FC, Arvin B, White RF, Miller A, Webb CL, Willette RN, Lysko PG, Feuerstein GZ: Tumor necrosis factor-alpha: a mediator of focal ischemic brain injury. Stroke 1997; 28:1233-1244.

3 Galic MA, Riazi K, Henderson AK, Tsutsui S, Pittman QJ: Viral-like brain inflammation during development causes increased seizure susceptibility in adult rats. Neurobiol Dis 2009;4:4.

4 Hagberg H, Mallard C, Jacobsson B: Role of cytokines in preterm labour and brain injury. BJOG 2005;112(suppl 1):16-18.

5 Rieckmann P: Cytokines and the CNS; in Ransohoff RM, Benveniste EN (eds): Cytokines and Multiple Sclerosis, ed 2. Boca Raton, Taylor \& Francis, 2006, pp 269-298.
6 Sandoval KE, Witt KA: Blood-brain barrier tight junction permeability and ischemic stroke. Neurobiol Dis 2008;32:200-219.

7 Yang GY, Gong C, Qin Z, Liu XH, Lorris BetZ A: Tumor necrosis factor- $\alpha$ expression produces increased blood-brain barrier permeability following temporary focal cerebral ischemia in mice. Brain Res Mol Brain Res 1999;69:135-143.

8 Banks WA, Kastin AJ, Durham DA: Bidirectional transport of interleukin-1 $\alpha$ across the blood-brain barrier. Brain Res Bull 1989;23: 433-437.

-9 Gutierrez EG, Banks WA, Kastin AJ: Murine tumor necrosis factor- $\alpha$ is transported from blood to brain in the mouse. J Neuroimmunol 1993;47:169-176.

10 Pan W, Kastin AJ: Tumor necrosis factor and stroke: role of the blood-brain barrier. Prog Neurobiol 2007;83:363-374.
-11 Cooper AL, Brouwer S, Turnbull AV, Luheshi GN, Hopkins SJ, Kunkel SL, Rothwell NJ: Tumor necrosis factor- $\alpha$ and fever after peripheral inflammation in the rat. Am J Physiol 1994;267:R1431-R1436.

12 Quan N, Banks WA: Brain-immune communication pathways. Brain Behav Immun 2007;21:727-735.

13 Banks WA, Kastin AJ, Gutierrez EG: Penetration of interleukin- 6 across the murine blood-brain barrier. Neurosci Lett 1994;179: 53-56.

14 Banks WA, Ortiz L, Plotkin SR, Kastin AJ: Human interleukin (IL) $1 \alpha$, murine IL- $1 \alpha$ and murine IL- $1 \beta$ are transported from blood to brain in the mouse by a shared saturable mechanism. J Pharmacol Exp Ther 1991;259:988-996 
15 Gray PW, Glaister D, Chen E, Goeddel DV, Pennica D: Two interleukin 1 genes in the mouse: cloning and expression of the cDNA for murine interleukin $1 \beta$. J Immunol 1986; 137:3644-3648.

-16 Banks WA, Farr SA, La Scola ME, Morley JE: Intravenous human interleukin-1 $\alpha$ impairs memory processing in mice: dependence on blood-brain barrier transport into posterior division of the septum. J Pharmacol Exp Ther 2001;299:536-541.

- 17 Banks WA, Kastin AJ, Ehrensing CA: Diurnal uptake of circulating interleukin- $1 \alpha$ by brain, spinal cord, testis and muscle. Neuroimmunomodulation 1998;5:36-41.

- 18 Sadowska GB, Patlak CS, Petersson KH, Stonestreet BS: Effects of multiple courses of antenatal corticosteroids on blood-brain barrier permeability in the ovine fetus. J Soc Gynecol Investig 2006;13:248-255.

$\checkmark 19$ Stonestreet BS, Patlak CS, Pettigrew KD, Reilly CB, Cserr HF: Ontogeny of bloodbrain barrier function in ovine fetuses, lambs, and adults. Am J Physiol 1996;271: R1594-R1601.

-20 Deng W, Pleasure J, Pleasure D: Progress in periventricular leukomalacia. Arch Neurol 2008;65:1291-1295.

-21 Cai Z, Pan ZL, Pang Y, Evans OB, Rhodes PG: Cytokine induction in fetal rat brains and brain injury in neonatal rats after maternal lipopolysaccharide administration. Pediatr Res 2000;47:64-72.

-22 Dammann O, Leviton A: Maternal intrauterine infection, cytokines, and brain damage in the preterm newborn. Pediatr Res 1997;42:1-8.

-23 Nelson KB, Dambrosia JM, Grether JK, Phillips TM: Neonatal cytokines and coagulation factors in children with cerebral palsy. Ann Neurol 1998;44:665-675.
24 Yoon BH, Romero R, Kim CJ, Koo JN, Choe G, Syn HC, Chi JG: High expression of tumor necrosis factor- $\alpha$ and interleukin- 6 in periventricular leukomalacia. Am J Obstet Gynecol 1997;177:406-411.

25 Yoon BH, Romero R, Yang SH, Jun JK, Kim IO, Choi JH, Syn HC: Interleukin-6 concentrations in umbilical cord plasma are elevated in neonates with white matter lesions associated with periventricular leukomalacia. Am J Obstet Gynecol 1996;174:1433-1440.

26 Back SA, Riddle A, Hohimer AR: Role of instrumented fetal sheep preparations in defining the pathogenesis of human periventricular white-matter injury. J Child Neurol 2006;21:582-589.

27 Petersson KH, Pinar H, Stopa EG, Faris RA, Sadowska GB, Hanumara RC, Stonestreet BS: White matter injury after cerebral ischemia in ovine fetuses. Pediatr Res 2002:768776.

28 Petersson KH, Pinar H, Stopa EG, Sadowska GB, Hanumara RC, Stonestreet BS: Effects of exogenous glucose on brain ischemia in ovine fetuses. Pediatr Res 2004;56:621-629.

29 Back SA: Perinatal white matter injury: the changing spectrum of pathology and emerging insights into pathogenetic mechanisms. Ment Retard Dev Disabil Res Rev 2006;12: 129-140.

30 McClure MM, Riddle A, Manese M, Luo NL, Rorvik DA, Kelly KA, Barlow CH, Kelly JJ, Vinecore K, Roberts CT, et al: Cerebral blood flow heterogeneity in preterm sheep: lack of physiologic support for vascular boundary zones in fetal cerebral white matter. J Cereb Blood Flow Metab 2008;28:995-1008.

-31 Riddle A, Luo NL, Manese M, Beardsley DJ Green L, Rorvik DA, Kelly KA, Barlow CH, Kelly JJ, Hohimer AR, Back SA: Spatial heterogeneity in oligodendrocyte lineage maturation and not cerebral blood flow predicts fetal ovine periventricular white matter injury. J Neurosci 2006;26:3045-3055.
32 Stonestreet BS, Sadowska GB, Leeman J, Hanumara RC, Petersson KH, Patlak CS: Effects of acute hyperosmolality on bloodbrain barrier function in ovine fetuses and lambs. Am J Physiol Regul Integr Comp Physiol 2006;291:R1031-R1039.

33 Altschul SF, Gish W, Miller W, Myers EW, Lipman DJ: Basic local alignment search tool. J Mol Biol 1990;215:403-410.

-34 Altschul SF, Wootton JC, Gertz EM, Agarwala R, Morgulis A, Schaffer AA, Yu YK: Protein database searches using compositionally adjusted substitution matrices. FEBS J 2005;272:5101-5109.

>35 March CJ, Mosley B, Larsen A, Cerretti DP, Braedt G, Price V, Gillis S, Henney CS, Kronheim SR, Grabstein K, et al: Cloning, sequence and expression of two distinct human interleukin-1 complementary DNAs. Nature 1985;315:641-647.

>36 Rothel JS, Hurst L, Seow HF, Pepin M, Berthon P, Corner LA, Wood PR: Analysis of ovine IL-1 $\beta$ production in vivo and in vitro by enzyme immunoassay and immunohistochemistry. Vet Immunol Immunopathol 1997;57:267-278.

37 Seow HF, Rothel JS, Wood PR: Expression and purification of recombinant ovine interleukin-1 $\beta$ from Escherichia coli. Vet Immunol Immunopathol 1994;41:229-239.

38 McWaters P, Hurst L, Chaplin PJ, Collins RA, Wood PR, Scheerlinck JP: Characterisation of monoclonal antibodies to ovine interleukin- 6 and the development of a sensitive capture ELISA. Vet Immunol Immunopathol 2000;73:155-165.

-39 Nonaka N, Banks WA, Mizushima H, Shioda S, Morley JE: Regional differences in PACAP transport across the blood-brain barrier in mice: a possible influence of strain, amyloid $\beta$ protein, and age. Peptides 2002;23:21972202. 